Abstracta Iranica

Revue bibliographique pour le domaine irano-aryen

Volume 34-35-36 | 2017

Comptes rendus des publications de 2011-2013

\title{
Dieter Weber. Taxation in Pahlavi Documents from Early Islamic times (late 7th Century CE)
}

\section{Rika Gyselen}

\section{(2) OpenEdition \\ 1 Journals}

Édition électronique

URL : http://journals.openedition.org/abstractairanica/42338

DOI : 10.4000/abstractairanica.42338

ISSN : 1961-960X

\section{Éditeur :}

CNRS (UMR 7528 Mondes iraniens et indiens), Éditions de l'IFRI

\section{Référence électronique}

Rika Gyselen, « Dieter Weber. Taxation in Pahlavi Documents from Early Islamic times (late 7th Century CE) », Abstracta Iranica [En ligne], Volume 34-35-36 | 2017, document 52, mis en ligne le 30 juillet 2017, consulté le 26 septembre 2020. URL : http://journals.openedition.org/abstractairanica/42338 ; DOI : https://doi.org/10.4000/abstractairanica.42338

\section{Ce document a été généré automatiquement le 26 septembre 2020}

Tous droits réservés 


\title{
Dieter Weber. Taxation in Pahlavi Documents from Early Islamic times (late 7th Century CE)
}

\author{
Rika Gyselen
}

\section{RÉFÉRENCE}

Dieter Weber. « Taxation in Pahlavi Documents from Early Islamic times (late 7th Century (E) », in: S. Tokhtasev et P. Luria, eds., Commentationes Iranicae. Vladimiro f. Aaron Livschits nonagenario donum natalicium. St. Pétersbourg, 2013, p. 171-181.

1 Publication (Berk. 34, 67, 154) et re-publication (Berk. 27) de quatre documents de l'Archive Pahlavi qui datent de la deuxième moitié du VII ${ }^{\mathrm{e}}$ s. et proviennent des environs de Qum. Y sont évoqués des taxes de natures diverses : les taxes foncières / xarg (Berk. 27), la capitation / gazìdag (Berk. 67), les taxes de ventes / bāj (Berk. 154), ainsi qu'une taxe 'drahm pad dēn' (Berk. 34). On remarquera dans ces différents contextes de taxation la présence soit d'un ōstāndār, soit d'un dar-handarzbed, fonctionnaires bien attestés à l'époque sassanide.

\section{AUTEURS}

RIKA GYSELEN

CNRS, Mondes iranien et indien 